\title{
Comparing Effect of Plant-derived Oils on Varroa destructor Infesting Honeybee, Apis mellifera
}

\author{
Ghada S. Refaei \\ Plant Protection Research Institute, ARC, Dokki, Giza, Egypt, Dr_ghadasalah@yahoo.com.
}

\begin{abstract}
In this research, we evaluated the application of different plant-derived oils (Thymol, Spearmint, Tea tree oil and mixture of spearmint and lemongrass) as control agents against the parasitic mite, Varroa destructor in the field. Four treatments of each tested material were applied to each colony during the treatment period. Data showed that all four tested compounds were effective in controlling Varroa oil and spearmint was the most effective substance as it had an efficiency of $85.9 \%$, followed by spearmint\& lemongrass and tea tree oils with an efficiency of $84.3 \%$ and $80.2 \%$, respectively. Meanwhile, Thymol treatment had a lower efficacy, $78.1 \%$ compared to the other treatments and the natural mortality in control colonies was $12.3 \%$,
\end{abstract}

Key words: Apis mellifera, Varroa destructor, Plant-derived oils, Infestation, Efficacy.

\section{INTRODUCTION}

Honeybees are important insects economically and ecologically. The ectoparasite mite, Varroa destructor, is considered as one of serious and worldwide pest of honeybees, causing weight loss, malformation, and a shortened life-span. It also serves as a vector of diseases that may lead to $100 \%$ bee mortality within few months (Kanga and James, 2002). Synthetic acaricides, Coumaphos, Apistan, Amitraz, Folbex, Folbex-Forte and Apitol have shown to provide effective control against V. destructor (Henderson, 1988; Martin, 1994; Gregorc and Poklukar, 2003). However, the Varroa mites have evolved a resistance to many of these compounds (Floris et al., 2004). Besides, these acaricides have significant drawbacks including contamination of honey; wax, and pollens (Calderone and Spivak, 1995).

Consequently, natural components might offer promising new avenues for the beekeeping industry. Many studies were carried out using some extracts of natural essential oil of various plants such as Rosemary, lemongrass, Camphor, Clove, Ginger roots, Fennel and Eucalyptus (Gregorc and Poklukar, 2003: Batish et al., 2008), to minimize the pesticide residues in the colonies and the acaricide resistance (Wallner et al.,1999).These products are generally inexpensive and had fewer health hazards to both man and honeybees (Melathopoulos et al., 2000; Koumad and Berkani 2016), Therefore, further work is needed to assess the effects of different natural compounds on mites, bees and colonies.

This study was conducted to evaluate the use of different plant-derived oils, Spearmint (Mentha spicata), Lemongrass (Cymbopogon citratus), Thymol (Thymus vulgaris) \& Tea tree oil (Melaleuca alternifolia), as alternative control methods that are safe, and environment friendly, against the parasitic mite, $V$. destructor.

\section{MATERIALS AND METHODS}

This study was carried out in an apiary at Giza governorate in March and April 2015. Fifteen colonies of the honeybee, A. mellifera were identified as being infested with $V$. destructor. Each colony consisted of 10 full-depth combs of worker bees and a queen. The colonies were divided into five equal groups. The first and second groups were treated with one of the following substances, Thymol \& Tea tree oil, respectively, while the third and fourth groups were treated with Spearmint oil \& a mixture of Spearmint and Lemongrass, respectively, the fifth group served as control.

One application of the tested materials was applied weekly for four successive weeks (treatment period), using a white sticky paper ( $3 \times 2$ inches) saturated with $2 \mathrm{ml}$ of each tested material \& held between frames of each hive. Control colonies received the carrier only without any test material.

To monitor and capture Varroa populations before and after treatments for calculating the mite mortality, a corrugated plastic bottom boards were inserted to all hives's bottom prior to each treatment under the wire/wood frame, where falling mites were trapped and the wire kept bees from removing it (Sammataro et al., 1998, Gregorc et al., 2018). These boards were removed, replaced by new ones daily and the trapped mites were counted. The hive entrances kept open during the experiment and applications were carried out after sunset, when all honeybees had returned to the hives. The number of Varroa individuals that not killed by the treatments was also obtained by counting the Varroa drop-down after using formic acid $(85 \%)$ for two consecutive weeks (treatment evaluation period).

The number of mites collected was recorded, the treatment efficiencies were estimated by comparing the number of Varroa that were killed before, and 
then again after each application.

The efficiency of each application was determined according to the formula of Colin (1990)

$$
X_{n}(\%)=\frac{A_{n} \times 100}{Z-Z_{n-1}}
$$

$A_{n}$ : number of mites collected throughout the days following each application; $\mathrm{Z}$ : total number of collected mites [mites collected after 4 applications + remaining mites collected after treatment evaluation period]; and $\mathrm{Z}_{\mathrm{n}-1}$ : number of collected mites before each application.

Data obtained in the Varroa control groups were analyzed statistically using analysis of variance (ANOVA) and means were separated by a least significant differences test in SAS.

\section{RESULTS AND DISCUSSION}

In the present study, several natural oils were used for the control of Varroa destructor, as they are biodegradable, safe for human and relatively inexpensive.

(Table, 1) indicated that the mean number of mites collected from the colonies that received four applications of the Spearmint (during the treatment period) was significantly higher (228.3 mites) than those that have received mixture of Spearmint \& Lemongrass, Tea tree oil and Thymol (152.6, 125 and 115.6 mites, respectively).

Essential oils of Spearmint have proven to be the most effective against Varroa destructor with a mean efficiency percentage of $(85.91 \pm 3.5)$, followed by the mixture of Spearmint, Lemongrass and tea tree \& Thymol oils with an efficiency of $(84.35 \pm 2.1 \%$, $80.21 \pm 3.2 \%$ and $78.17 \pm 3.4 \%$ ) compared with the control group $(12.3 \pm 1.07 \%)$ at $5 \%$ significant levels.

Our data showed that all essential oils were effective against Varroa. The averages efficacies of four essential oils were at similar levels, but Thyme essential oil had a lower effect compared with the others (Fig. 1). ANOVA showed significant differences between treatments with essential $(\mathrm{F}=$ $119.78, \mathrm{P}<0.0001$ )

Several authors have evaluated essential oils and their components as control agents for Varroa (Sammataro et al., 1998; Imdorf et al., 1999; Ariana et al., 2002; Ismail et al., 2006), and indicated that many of these compounds are biologically toxic to Varroa without injuring bees, due to the activation of the defense behavior mechanisms of honeybee workers by these plant oils against Varroa mite (Islam et al., 2016).

In this study, the Spearmint oil was the most effective against Varroa, which in agreement with Ariana et al., 2002; Koumad and Berkani, 2016, who concluded that the Spearmint oil was effective against Varroa mite with a good effectiveness, greater than $80 \%$, but ineffective at low dose.

Also, Spearmint \& Lemongrass mixture gave high Varroa mortality; similarly, Islam et al., 2016 recorded $80.12 \%$ of mite mortality after Lemongrass treatment.

Table (1). Effect of different plant-derived oils against $V$. destructor in A. mellifera colonies.

\begin{tabular}{|c|c|c|c|c|}
\hline \multirow[b]{2}{*}{ Group } & \multirow[b]{2}{*}{$\begin{array}{l}\text { Colony } \\
\text { No. }\end{array}$} & \multicolumn{2}{|c|}{ Number of dead/fallen mites } & \multirow{2}{*}{$\begin{array}{l}\text { Percentage of } \\
\text { treatment efficiency }\end{array}$} \\
\hline & & $\begin{array}{l}\text { Total number of collected mites } \\
\text { after the treatment period }\end{array}$ & $\begin{array}{l}\text { Total number of mites in } \\
\text { each colony }\end{array}$ & \\
\hline \multirow{3}{*}{ Thymol } & 1 & 121 & 161 & 75.15 \\
\hline & 2 & 84 & 113 & 74.33 \\
\hline & 3 & 142 & 167 & 85.02 \\
\hline Mean \pm SE & & $115.6 \pm 16.9$ & $147 \pm 17.07$ & $78.17 \pm 3.4^{\mathrm{a}}$ \\
\hline \multirow{3}{*}{ Tea tree oil } & 1 & 98 & 113 & 86.72 \\
\hline & 2 & 140 & 184 & 76.08 \\
\hline & 3 & 137 & 176 & 77.84 \\
\hline Mean \pm Se & & $125 \pm 13.5$ & $157.6 \pm 22.4$ & $80.21 \pm 3.2^{\mathrm{a}}$ \\
\hline \multirow{3}{*}{ Spearmint } & 1 & 251 & 283 & 88.69 \\
\hline & 2 & 187 & 237 & 78.90 \\
\hline & 3 & 247 & 274 & 90.14 \\
\hline Mean \pm SE & & $228.33 \pm 20.6$ & $264.6 \pm 14.07$ & $85.91 \pm 3.5^{\mathrm{a}}$ \\
\hline \multirow{3}{*}{$\begin{array}{l}\text { Spearmint \& } \\
\text { Lemongrass }\end{array}$} & 1 & 129 & 146 & 88.35 \\
\hline & 2 & 173 & 214 & 80.84 \\
\hline & 3 & 156 & 186 & 83.87 \\
\hline Mean \pm SE & & $152.6 \pm 12.8$ & $182 \pm 19.7$ & $84.35 \pm 2.1^{\mathrm{a}}$ \\
\hline \multirow{3}{*}{ Control } & 1 & 19 & 139 & 13.6 \\
\hline & 2 & 9 & 88 & 10.2 \\
\hline & 3 & 28 & 212 & 13.2 \\
\hline Mean \pm SE & & $18 \pm 9.5$ & $146.33 \pm 35.8$ & $12.36 \pm 1.07^{\mathrm{b}}$ \\
\hline
\end{tabular}


On the other hand, Thymol revealed a lower efficiency $(78.1 \%)$ in reducing Varroa mite when compared to other oils in the present study. But, Ariana et al., 2002 and May-Itza et al., 2007 found that Thymol and Thymol gel could eliminate $~ 90 \%$ of the mites in honeybee colonies.

Similarly, several authors evaluated this compound as control agent for Varroa destructor mite (Mattila et al., 2000; Emsen and Dodologlu, 2009). However, significant bee mortality was reported when powdered Thymol was used against $V$. destructor, which was probably a consequence of the high surface area of Thymol or high ambient temperatures (Chiesa, 1991 and Gal et al. 1992). Therefore, numerous factors contribute to the overall efficacy of acaricides such as the concentration of compounds, delivery method, ambient temperature, and colony and apiary environment (Calderone and Spivak, 1995).

Generally, using essential oils seems to be promising as the best control method for Varroa mite (present study and previous research), it occurs in nature, safe to environment, relatively inexpensive, and support the need to overcome resistance issues with currently registered acaricides. Therefore, further work is needed to assess the effects of these compounds on mites, bees and colonies.

\section{REFERENCES}

Ariana, A.; Ebadi, R. and Tahmasebi, G. 2002. Laboratory evaluation of some plant essences to control Varroa destructor (Acari: Varroidae). Exp. Appl. Acarol., 27(4): 319-327.

Batisha, D. R.; Singh, H. P.; Kohli, R. K. and Kaur, S. 2008. Eucalyptus essential oil as a natural pesticide. For. Ecol. Manage., 256: 2166-2174

Calderone, N. W. and Spivak, M. 1995. Plant extracts for control of the parasitic mite, Varroa jacobsoni (Acari: Varroidae) in colonies of the western honeybee (Hymenoptera: Apidae). J. Econ. Entomol., 88(5): 1211-1215.

Chiesa, F. 1991. Effective control of varroatosis using powdered thymol. Apidologie, 22(2): 135-145.

Colin, M. E. 1990. Essential oils of Labiatae for controlling honeybee varroasis. J. Appl. Entomol., 110: 19-25.

Emsen, B and Dodologlu, A. 2009. The Effects of Using Different Organic Compounds against Honey Bee Mite (Varroa destructor Anderson and Trueman) on Colony Developments of Honey Bee (Apis mellifera L.) and Residue Levels in Honey. Journal of Animal and Veterinary Advances. (8), 1004-1009.

Floris, I.; Satta, A.; Cabras, P.; Garau, V. L. and Angioni, A. 2004. Comparison between two thymol formulations in the control of Varroa destructor: Effectiveness, persistence, and residues. J. Econ. Entomol. 97:187-191.

Gal, H.; Slabezki, Y. and Lensky, Y. 1992. A preliminary report on the effect of origanum oil and thymol applications in honeybee (Apis mellifera L.) colonies in a subtropical climate on population levels of Varroa jacobsoni. Bee Sci., 2(4): 175-180.

Gregorc, A. and Poklukar, J. 2003. Rotenone and oxalic acid as alternative acaricidal treatments for Varroa destructor in honeybee colonies. Vet. Parasitol., 111: 351-360.

Gregorc, A.; Alburaki, M.; Sampson, B.; Knight, P. R. and Adamczyk, J. 2018. Toxicity of Selected Acaricides to Honey Bees (Apis mellifera) and Varroa (Varroa destructor Anderson and Trueman) and Their Use in Controlling Varroa within Honey Bee Colonies. Insects. 9 (2):55.

Henderson, C. 1988. Tests of chemical control agents for Varroa jacobsoni in honeybee packages. pp. 380-386. In: G.R. Needham, R.E. Page, Jr. M. Delfinado-Baker and C. Bowman (eds.), Africanized Honeybees and Bee Mites, E. Horwood, Chichester.

Imdorf, A.; Bogdanov, S.; Ochao, R. I. and Calderone, N. W. 1999. Use of essential oils for the control of Varroa jacobsoni Oud. in honeybee colonies. Apidologie, 30(2-3): 209-228.

Islam, N.; Amjad, M.; Haq, E.; Stephen, E. and Naz, F. 2016. Management of Varroa destructor by essential oils and formic acid in Apis mellifera Linn. Colonies. Journal of Entomolgy and Zoology Studies; 4(6):97-104.

Ismail, A. M.; Ghoniemy, A. H. and Owayss, A. A. 2006. Combatting honeybee Varroa mites by plant oils alone or in an IPM program. The 2nd conference of Farm Integrated Pest Management, 16-18 Jan., Fac. Agric., Fayoum Univ., 172-185 pp., 2006

Kanga, L. H. and James, R. R. 2002. Varroa control with fungal pathogens may be an option soon. Amer. Bee J., 142(7): 519-520.

Koumad, S. and Berkani, M. L. 2016. Comparative Study of the Activity Acaricide of Four Essentials Oils on Varroa destructor Mite of the Honey Bee Apis mellifera in the Center of Algeria. AmericanEurasian Journal of Scientific Research 11 (6): 447-452.

Martin, S. J. (1994). Ontogensis of the mite Varroa jacobsoni Oudemans in worker brood of the honeybee Apis mellifera L. under natural conditions. Exp. Applied Acarol., 18: 87-100.

Mattila, H. R.; Otis, G.W.; Daley, J. and Schulz, T. 2000. Trials of Apiguard, a thymol based miticide. Part 2. Non-target effects on honeybees. American Bee Journal, 140: 68-70.

May-Itza, W. J.; Medina, L. A. and Marrufo Olivares, 
J. C. 2007. Effectiveness of thymol based jells for the control of Varroa destructor mite that infests Apis mellifera honey bee colonies, under tropical conditions in Yucatan, Mexico. Vet. Mex., 38(1); 1-8

Melathopoulos, A. P.; Winston, M. L.; Whittington, R.; Smith, T.; Lindberg, C.; Mukai, A. and Moore, M. 2000. Comparative laboratory toxicity of neem pesticides to honeybees (Hymenoptera: Apidae), their mite parasites Varroa jacobsoni (Acari: Varroidae) and Acarapis woodi (Acari:
Tarsonemidae), and brood pathogens Paenibacillus larvae and Ascophaera apis. J. Econ. Entomol., 93(2): 199-209.

Sammataro, D.; Degrandi-Hoffman, G.; Needham, G.; and Wardell, G. 1998. Some volatile plant oils as potential control agents for Varroa mites (Acari: Varroidae) in honeybee colonies (Hymenoptera: Apidae). Am. Bee J., 138(9): 681685.

Wallner, K. 1999. Varroacides and their residues in bee products. Apidologie.30:235-248. 